\title{
Pembelajaran dengan Cooperative Integrated Reading and Composition (CIRC) dalam Meningkatkan Kemampuan Menemukan Pokok Pikiran
}

\author{
Awatik \\ SDN 004/V Kuala Tungkal, Kab. Tanjung Jabung Barat, Provinsi Jambi \\ email: awatik.sd004@gmail.com
}

\begin{abstract}
This study aims to improve students' abilities in finding points of thought. These efforts are carried out by applying the CIRC learning model. This research is a classroom action research conducted in class V-C SDN 004 / V Kuala Tungkal. The study was conducted in 2 cycles. There were 33 students who were the subjects in this study. The results showed a positive impact from the application of the CIRC model. This is indicated from the increase in the average student test score of 61.90 in the first cycle to 78.79 in the second cycle. In addition, the number of students who exceeded the minimum grade also increased, namely $51,52 \%$ (17 students) in the first cycle to 78,79 (26 students) in the second cycle.
\end{abstract}

Keywords: CIRC, find the main idea.

\begin{abstract}
Abstrak
Penelitian ini bertujuan untuk meningkatkan kemampuan siswa dalam menemukan pokok pikiran. Upaya tersebut dilakukan dengan menerapkan model pembelajaran CIRC. Penelitian ini merupakan penelitian tindakan kelas yang dilakukan di kelas V-C SDN 004/V Kuala Tungkal. Penelitian dilakukan dalam 2 siklus. Terdapat 33 siswa yang menjadi subjek dalam penelitian ini. Hasil penelitian menunjukkan adanya dampak positif dari penerapan model CIRC. Hal tersebut diindikasi dari peningkatan rata-rata skor tes siswa yakni 61,90 pada siklus I menjadi 78,79 pada siklus II. Selain itu, jumlah siswa yang melampaui nilai minimal juga mengalami peningkatan, yakni 51,52\% (17 siswa) pada siklus I menjadi 78,79 (26 siswa) pada siklus II.
\end{abstract}

Kata Kunci: CIRC, menemukan ide pokok.

\section{PENDAHULUAN}

Terdapat beberapa keterampilan

yang harus dikuasai siswa dalam berbahasa. Satu diantara keterampilan tersebut adalah keterampilan membaca yang memiliki peranan penting dalam perkembangan siswa (Kurniaman \& Noviana, 2016; Samniah, 2015; Sofiyah, 2015). Membaca bertujuan untuk memperoleh informasi yang berguna dalam narasi/ bahan bacaan, memperoleh ilmu pengetahuan yang 
bersifat baru (Rahmawati, 2017). Dengan memperbanyak membaca maka seseorang dapat memperluas cakupan pengetahuan dan menggali banyak informasi. Pada bidang sains misalnya, kemampuan membaca menjadi sangat penting karena menurut peneliti (seperti, Taqwa, 2018; Taqwa \& Faizah, 2016; Taqwa, Faizah, \& Rivaldo, 2019; Taqwa \& Hidayat, 2017) siswa sering memiliki pemahaman yang terpotong-potong sehingga penting bagi siswa untuk banyak membaca. Semakin banyak dan sering seseorang dalam membaca suatu sumber informasi, maka semakin komprehensif dan mendalam pula wawasannya. Hal tersebut sesuai dengan tujuan pembelajaran yakni merubah kompetensi siswa menjadi lebih baik (Taqwa, Astalini, \& Darmaji, 2015).

Siswa tak akan pernah lepas dari bahan bacaan atau wacana dalam melakukan kegiatan atau aktivitas membaca. Membaca merupakan aktivitas yang dilakukan untuk memperoleh pesan atau pengetahuan dari suatu bacaan. Kemampuan dalam memahami isi paragraf bergantung pada kemampuan dalam menemukan isi paragraf. Sehingga kemampuan dalam menemukan pokok pikiran merupakan poin penting yang harus dikuasai oleh siswa (Purba, 2018; Rapita, 2018; Triandy, 2017).

Kondisi awal siswa-siswa kelas V-C SDN 004/V Kuala Tungkal tahun ajaran 2018/2019 secara keseluruhan telah dapat membaca suatu teks atau bahan bacaan. Namun, kemamapuan membaca siswa masih cenderung belum terlalu baik, karena siswa belum mampu menemukan pokok pikiran dari paragraf yang dibacanya dengan benar. Hal tersebut didukung dengan hasil ulangan harian siswa yang masih cenderung rendah dan masih dibawah KKM. Oleh karena itu, permasalahan ini perlu mendapatkan perhatian khusus agar dapat terpecahkan atau minimal tereduksi.

Pelaksanaan pembelajaran yang telah berlangsung lebih sering dilakukan dengan konvensional, dengan guru sebagai pusat pembelajaran. Pembelajaran demikian menimbulkan kesan yang kurang menggairahkan dan cenderung membosankan bagi siswa (Agustinawati, 2014; Husna \& Pinem, 2011; Nuraisah, Irawati, \& Hanifah, 2016; Saparwadi, 2016). Sehingga siswa menginginkan cara belajar yang bervariasi (Hasan, 2015). Dari permasalahan yang telah teridentifikasi dapat dinyatakan bahwa rendahnya kemampuan siswa dalam menemukan pokok pikiran sebuah paragraf justru bersumber dari gurunya. Karena pembelajaran yang dirancang oleh guru selama ini cenderung statis sehingga siswa mudah merasa bosan.

Penting bagi guru untuk mengimplementasikan model pembelajaran yang sesuai agar siswa lebih termotivasi belajar. Salah satu model tersebut adalah Cooperative Integrated Reading and Composition 
(CIRC) yang berguna untuk mengatasi permasalahan dalam pembelajaran bahasa Indonesia (Purnawasari, 2017) terutama dalam hal literasi membaca (Putrawan, Sudana, \& Tastra, 2017) dan untuk membantu siswa dalam meningkatkan kemampuan menemukan ide pokok/pokok pikiran dari suatu paragraf.

CIRC termasuk salah satu model pembelajaran cooperative learning (Delviani, Djuanda, \& Hanifah, 2016; Eviliyanto \& Gultom, 2017; Yeni \& Kalsum, 2012; Yudasmini, Marhaeni, \& Jampel, 2015; Yuliana, Walanda, \& Ratman, 2014), yang mana pada awalnya CIRC adalah salah satu model pengajaran kooperatif terpadu yang dikhususkan pada membaca dan menulis. Dalam praktiknya siswa dibentuk ke dalam kelompokkelompok untuk saling bekdiskusi dengan tujuan untuk menyelesaikan masalah dan mencapai tujuan pembelajaran. Dengan berkelompok, siswa dapat lebih banyak berinteraksi dan bertukar pikiran dengan siswa lain untuk bekerjasama dalam hal menyelesaikan tugas yang telah dirancang oleh guru sehingga dapat meningkatkan kemampuan sosial mereka. Oleh karena itu, penelitian ini akan difokuskan dalam meningkatkan kemampuan siswa dalam menentukan pokok pikiran dengan menerapkan CIRC.

\section{METODE PENELITIAN}

Penelitian dilakukan di SDN 004/V
Kuala Tungkal kabupaten Tanjung Jabung Barat pada tahun ajaran 2018/2019, pada kelas V-C dengan jumlah siswa sebanyak 33 orang. Penelitian ini termasuk jenis penelitian kualitatif dengan desain PenelitianTindakan Kelas (PTK). Desain peneilitian yang dilakukan mengikuti model yang dikembangkan oleh Elliot (1991). Skema penelitian yang dilakukan seperti yang ditunjukkan Gambar 1.

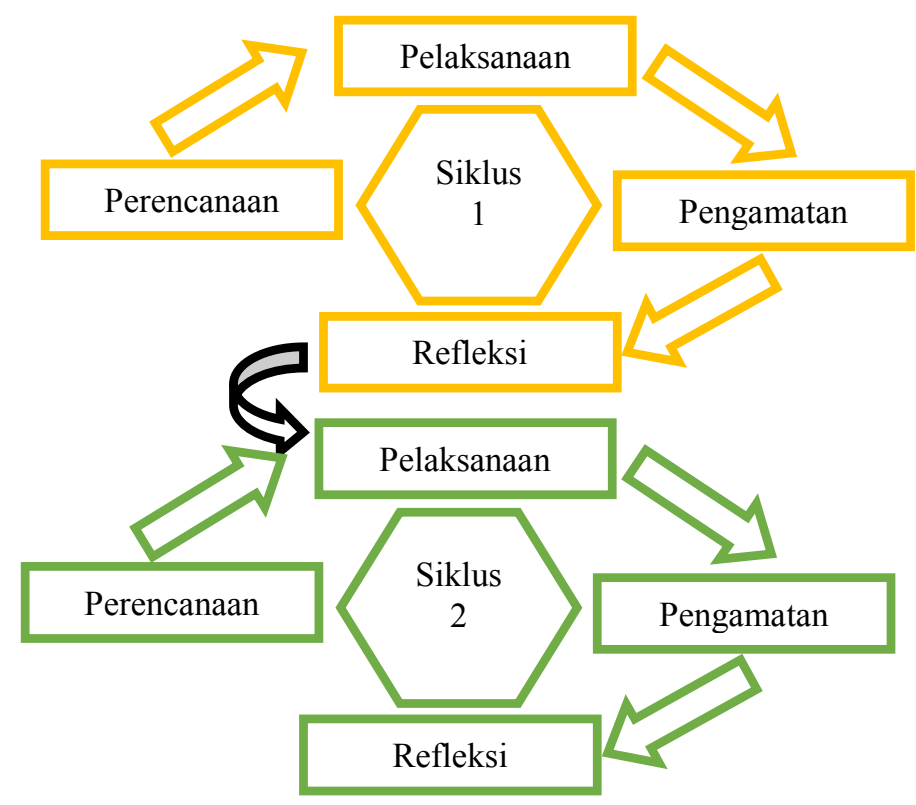

Gambar 1. Skema Pelaksanaan Tindakan

Dalam penelitian ini dikumpulkan data kuantitatif dan kualitatif. Data kuantitatif yang dikumpulkan berupa skor nilai siswa dalam menemukan pokok pikiran/ ide pokok sebuah paragraf dan persentase dari jumlah siswa yang mencapai KKM yakni 68, serta skor observasi keterlaksanaan pembelajaran sesuai 
moder CIRC, dan Data kualitatif yang dikumpulkan berupa data hasil wawancara dengan siswa kelas V-C.

Pengumpulan data yang digunakan dalam penelitian ini adalah dengan melakukan observasi, dokumentasi dan tes. Menurut (Kusumah \& Dwitagama, 2010), observasi merupakan serangkaian proses kegiatan yang bertujuan untuk pengambilan data dimana peneliti atau pengamat melihat secara langsung situasi penelitian. Observasi yang dilakukan dalam penelitian dibatasi pada kelas V-C, yang kemudian siswa di kelas tersebut dijadikan sebagai subjek penelitian.

\section{Dokumentasi}

adalah

serangkaian kegiatan yang dilakukan untuk menghimpun informasi yang mendukung tujuan penelitian melalui penelusuran dokumen-dokumen yang sudah ada. Dokumentasi dapat berupa daftar nama siswa dan dokumen lain yang diperoleh seperti daftar nilai siswa yang mendukung putusan atau klaim penelitian, hasil pekerjaan siswa, dan gambaran selama proses pembelajaran siswa di dalam kelas. Terakir, tes merupakan serangkaian kegiatan untuk menghimpun informasi dari siswa dengan memberikan serangkaian tugas atau perintah yang harus dikerjakan oleh siswa (Arikunto, 2006).

Agar keabsahan dan kebenaran data yang dikumpulkan dalam penelitian serta untuk memperkuat klaim yang akan dimabil dalam kesimpulan penelitian maka peneliti menggunakan teknik triangulasi. Jenis teknik triangulasi yang digunakan dalam penelitian ini adalah triangulasi sumber. Triangulasi sumber diperoleh dari siswa, peneliti, dan guru kelas. Sedangkan pengujian validitas instrumen, peneliti menggunakan validitas isi. Validitas isi adalah ukuran yang digunakan untuk mengetahui ketepatan dari suatu instrumen (tes) bila ditinjau dari aspek isi (materi) dengan tujuan untuk mengetahui sejauh mana siswa menguasai materi pelajaran.

Dalam penelitian tindakan kelas ini, hal yang ingin dicapai adalah adalah adanya peningkatan kemampuan menemukan pokok pikiran melalui implementasi CIRC. Kriteria Ketuntasan yang telah ditentukan yakni tercapainya skor minimal sebesar 68 oleh siswa. Kemampuan dalam menentukan pokok pikiran meggunakan soal 7 pilihan ganda untuk tiap siklusnya. Soal yang digunakan merupakan soal yang telah divalidasi dan memenuhi kriteria kelayakan butir soal. Skor siswa ditentukan dengan menggunaan persamaan persentase, dengan skor maksimal 100.

Keterlaksanaan pembelajaran didasarkan pada lembar observasi yang telah dirancang. Lembar observasi dirancang untuk mengamati pelaksanaan pembelajaran yang dilakukan guru dengan beberapa komponen, yakni (1) fase orientasi; (2) fase organisasi; (3) fase pengenalan konsep; (4) fase eksplorasi dan aplikasi; (5) fase publikasi; dan (6) fase penguatan dan refleksi. Konstruksi butir 
kegiatan yang telah diamati disesuaikan dengan sintaks pembelajaran CIRC. Skor maksimal untuk tiap aspek adalah 100 . Kriteria penilaian keterlaksanaan kegiatan pembelajaran ditunjukkan oleh Tabel 1 .

Tabel 1. Kriteria Penilaian Keterlaksanaan Kegiatan Pembelajaran

\begin{tabular}{lll}
\hline No & Rentang Nilai & Kriteria \\
\hline 1 & $P \geq 90$ & Sangat baik \\
2 & $80 \leq P<90$ & Baik \\
3 & $70 \leq P<80$ & Cukup baik \\
4 & $60 \leq P<70$ & Kurang baik \\
5 & $P<60$ & Sangat kurang baik \\
\hline
\end{tabular}

HASIL DAN PEMBAHASAN

Hasil dan pembahasan dalam artikel ini secara umum terdiri dari dua poin besar, yakni pelaksanaan pembelajaran dalam tiap siklus dan skor kemampuan menemukan pokok pikiran.

\section{Pembelajaran dalam Siklus I}

Pelaksanaan

kegiatap)

pembelajaran dengan

mengimplementasikan model CIRC. Selama kegiatan pembelajaran, guru diamati oleh observer yang mencatat keterlaksanaan kegiatan pembelajaran. Data keterlaksanaan pembelajaran seperti yang ditunjukkan Tabel 2.

Tabel 2. Data Observasi Keterlaksanaan Pembelajaran Siklus I

\begin{tabular}{lll}
\hline No & Aspek yang Diamati & Skor \\
\hline 1 & Fase orientasi & 90,00 \\
2 & Fase organisasi & 85,00 \\
3 & Fase pengenalan konsep & 95,00 \\
4 & Fase eksplorasi dan aplikasi & 95,00 \\
5 & Fase publikasi & 85,00
\end{tabular}

\begin{tabular}{ccc}
6 & Fase penguatan dan refleksi & 75,00 \\
\hline Rata-Rata & 87,50 \\
\hline
\end{tabular}

Berdasarkan data tersebut, keterlaksanaan pembelajaran dengan menerapkan model CIRC dalam kategori baik, yakni dengan rata-rata skor aspek yang diamati adalah 87,50. Hal tersebut dikarenakan dalam proses pembelajaran, perencanaan benar-benar dirancang dengan sematang mungkin dengan mengikuti sintaks yang ada. Sintaks model pembelajaran CIRC yang dilakukan adalah sebagai berikut (Sastika \& Vh, 2013).

(1) (1) Fase orientasi

Pada fase orientasi, kegiatan pembelajaran dilakukan dengan memberikan apersepsi dan pengetahuan awal yang berkaitan dengan materi yang akan disampaikan. Selain itu, guru memaparkan tujuan pembelajaran yang akan dilakukan kepada siswa.

\section{(2) Fase organisasi}

Kegiatan ini bertujuan untuk mengorganisir siswa. Fase orgranisasi dilakukan dengan membagi siswa menjadi kelompok. Pembagian kelompok dilakukan dengan memperhatikan tingkat heterogenitas siswa berdasarkan tingkat kognitif.

(3) (3) Fase pengenalan konsep

Tahap ini merupakan tahap inti dalam pembelajaran dan merupakan bagian esensial. Pada tahap ini guru mengenalkan konsep atau hal-hal baru yang harusnya dipahami oleh siswa. Pengenalan dilakukan dengan pemaparan 
langsung, melalui buku, atau media lainnya.

\section{(4) Fase eksplorasi dan aplikasi}

Pada tahap ini, siswa diajak untuk mengeksplor pengetahuan yang telah mereka miliki. Tahap ini memberi peluang pada siswa untuk mengungkap pengetahuan awal maupun mengembangkan pengetahuan baru, dan menggunakan pengetahuan tersebut untuk menjelaskan fenomena tertentu.

\section{(5)Fase publikasi}

Publikasi yang dimaksud dalam fase ini adalah usaha siswa untuk menyampaikan pengetahuan baru yang telah mereka miliki. Siswa dituntut untuk mampu mengomunikasikan kepada teman-temannya.

\section{(6) Fase penguatan dan refleksi}

Terakhir, pada tahap penguatan dan refleksi guru memberikan penguatan berhubungan dengan materi yang dipelajari. Selanjutnya,setiap siswa diberikan kesempatan untuk refleksi dan mengevaluasi hasil belajar yang telah mereka alami.

Pada dasarnya, kegiatan pembelajaran dilaksanakan sesuai dengan rancangan yang telah dibuat sebelumnya. Hanya saja siswa tidak begitu banyak merespon ketika kegiatan penguatan dan refleksi. Hal tersebut dimungkinkan oleh beberapa hal, seperti malu untuk bertanya, tidak memahami dengan baik apa yang seharusnya mereka pahami, atau sebab-sebab lainnya. Berdasarkan hal tersebut maka pada siklus II perlu diadakan perbaikan pada fase penguatan dan refleksi.

\section{Pembelajaran dalam Siklus II}

Pada pembelajaran siklus II, pembelajaran dilaksanakan dengan lebih baik. Hal tersebut dikarenakan pada siklus II, guru telah melakukan kegiatan refleksi berdasarkan kekurangan dari pelaksanaan pembelajaran siklus I. Data keterlaksanaan pembelajaran seperti yang ditunjukkan Tabel 3.

Tabel 3. Data Observasi Keterlaksanaan Pembelajaran Siklus II

\begin{tabular}{lll}
\hline No & Aspek yang Diamati & Skor \\
\hline 1 & Fase orientasi & 90,00 \\
2 & Fase organisasi & 95,00 \\
3 & Fase pengenalan konsep & 95,00 \\
4 & Fase eksplorasi dan aplikasi & 95,00 \\
5 & Fase publikasi & 90,00 \\
6 & Fase penguatan dan refleksi & 95,00 \\
\hline \multicolumn{2}{c}{ Rata-Rata } & 93,33 \\
\hline
\end{tabular}

Berdasarkan pelaksanaan pembelajaran pada siklus II, maka kegiatan pada tiap fase dilakukan perbaikan, terutama pada fase ke-6. Ratarata skor aspek yang diamati adalah 93,33. Pada siklus I, tahap evaluasi pembelajaran oleh siswa tidak berjalan dengan baik jika siswa diminta merefleksikan hal-hal yang belum dipahami. Pada tahap ini, siswa diminta untuk menuliskan secara spesifik hal-hal yang dipahami dan tidak dipahami. Guru menuliskan angket untuk melakukan kegiatan self assessment. Angket berisi pernyataan terkait hal-hal penting yang 
harus dipahami oleh siswa. Siswa diminta untuk menuliskan persentase pemahaman yang mereka peroleh dari kegiatan pembelajaran. Hasil isian angket tersebut dapat ditindak lanjuti untuk pembelajaran-pembelajaran kedepannya.

\section{Kemampuan dalam Menemukan Pokok Pikiran}

Kemampuan siswa dalam menemukan pokok pikiran mengalami peningkatan dari siklus I ke siklus II. Persentase siswa berdasarkan perolehan skor seperti yang disajikan Gambar 2 .

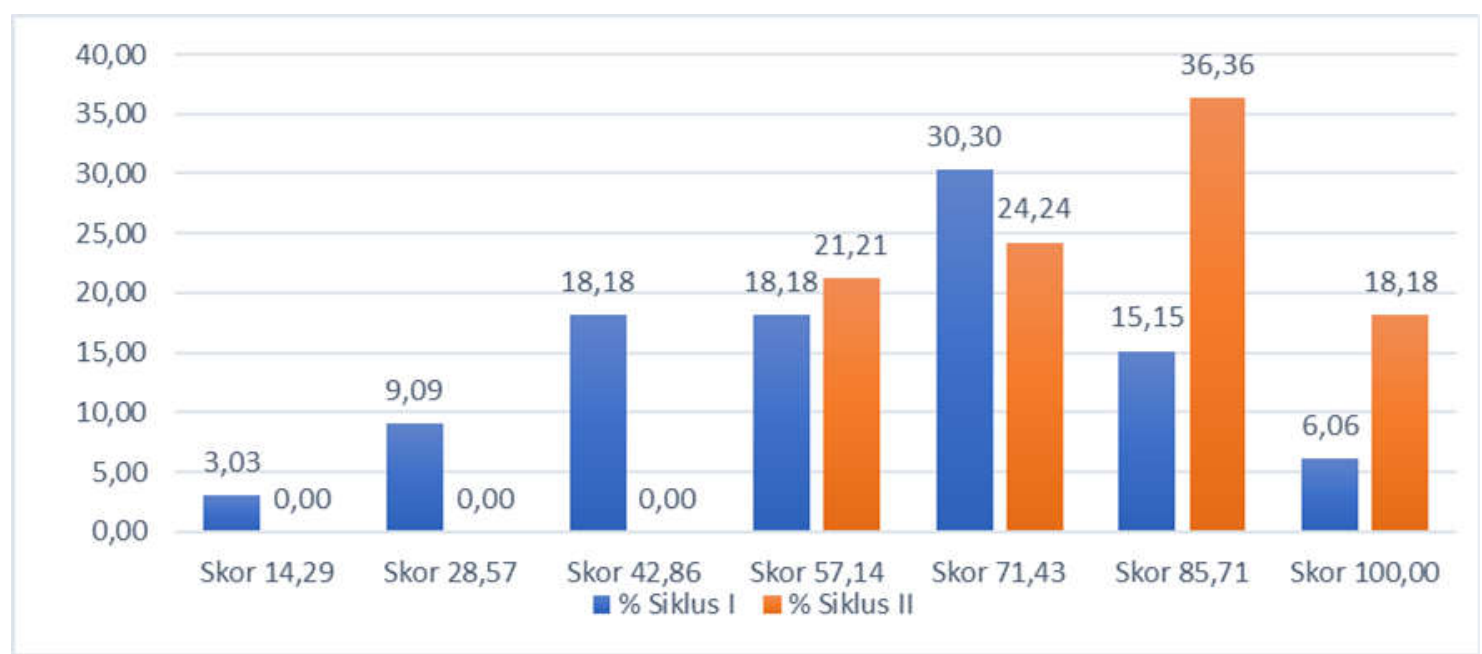

Gambar 2. Persentase Berdasarkan Perolehan Skor pada Evaluasi tiap Siklus.

Berdasarkan Gambar 2, jumlah siswa yang mencapai nilai minimal, yakni 68 mengalami peningkatan. Pada siklus I, terdapat $51,52 \%$ (17 siswa) yang mencapai nilai di atas 68. Pada siklus II, jumlah siswa yang memperoleh nilai di atas 68 naik menjadi 78,79\% (26 siswa). Dari nilai rata-rata siswa juga mengalami peningkatan. Pada siklus I, rata-rata skor siswa adalah 61,90 dan menjadi 78,79 pada siklus II.

Berdasarkan persentase siswa yang memperoleh skor, pada siklus I sebanyak 3,03\% (1 siswa) memperoleh skor 14,29; 9,09\% (3 siswa) memperoleh skor 28,$57 ; \quad 18,18 \% \quad$ (6 siswa) memperoleh skor 42,86; 18,18\% (6 siswa) memperoleh skor 57,14; 30,30\% (10 siswa) memperoleh skor 71,43; $15,15 \%$ (5 siswa) memperoleh skor 85,71 ; dan $6,06 \%$ (2 siswa) yang memperoleh skor 100. Pada siklus II, $21,21 \%$ (7 siswa) memperoleh skor 57,$14 ; 24,24 \%$ (8 siswa) memperoleh skor 71,$43 ; \quad 36,36 \% \quad(12$ siswa $)$ memperoleh skor 85,71 ; dan $18,18 \%$ (6 siswa) memperoleh skor 100.

Selain dari nilai tersebut, klaim terkait efektifitas penerapan model CIRC ini didukung dengan hasil wawancara yang dilakukan pada 5 siswa yang diambil secara acak. Berdasarkan hasil wawancara, siswa merasa lebih tertarik ketika belajar dengan menggunakan 
model CIRC. Mereka menyebutkan bahwa bekerja secara berkelompok lebih menyenangkan dibandingkan hanya dengan ceramah.

Peningkatan kemampuan siswa dalam menentukan pokok pikiran ini dikarenakan pembelajaran dilaksanakan secara kooperatif, tidak lagi dilaksanakan hanya dengan metode ceramah. Siswa menjadi lebih termotivasi jika pembelajaran dilaksanakan secara kooperatif (dengan beragam tipe) (Budiawan, 2013; Chrisnawati, 2007; Dörnyei, 1997; Maisaroh, 2011; Mulyana, Hanifah, \& Jayadinata, 2016; Nichols \& Miller, 1994). Dengan pembelajaran kooperatif, siswa lebih tertarik untuk mengikuti proses pembelajaran. Beberapa kelebihan pembelajaran kooperatif diantaranya adalah (1) mengembangkan tingkah laku kooperatif; (2) mamcu terbentuknya ide baru; (3) memperbaiki hubungan antara siswa; (4) peningkatan prestasi akademik; dan (5) mengembangkan solidaritas sosial.

Pembelajaran dengan model CIRC, yang merupakan salah satu model pembelajaran kooperatif sebenarnya telah diteliti oleh banyak peneliti sebelumnya. Seperti hasil penelitian yang dilakukan Supangat (2016) menunjukkan bahwa model pembelajaran CIRC dapat meningkatkan kemampuan membaca dan menulis siswa pada mata pelajaran kitab kuning. Pada pembelajaran Bahasa Indonesia, model pembelajaran CIRC berguna dalam meningkatkan keterampilan membaca (Kariesma,
Zulaikha, Ganing, \& Hum, 2014) dan menulis (Halimah, 2014; Tristiantari \& Sumantri, 2016), memahami cerita (Pratiwi, 2012), membaca pemahaman (dokkai) (Pratita, 2017), menulis karangan argumentasi (Yulismayanti, 2017), menulis narasi (Ramadhanti, 2017), memahami nilai-nilai edukatif dalam cerpen (Sukaryantini, 2013), dan seperti yang dilakukan peneliti, CIRC dapat meningkatkan kemampan menemukan gagasan utama (Farboy, 2013).

\section{SIMPULAN}

Implementasi model pembelajaran CIRC dapat meningkatkan kemampuan kemampuan siswa dalam menemukan pokok pikiran. Hal tersebut diindikasi dari peningkatan rata-rata skor tes siswa yakni 61,90 pada siklus I menjadi 78,79 pada siklus II. Selain itu, jumlah siswa yang melampaui nilai minimal juga mengalami peningkatan, yakni 51,52\% (17 siswa) pada siklus I menjadi 78,79 (26 siswa) pada siklus II. Dengan pembelajaran CIRC siswa merasa lebih termotivasi, yang diindikasi dari antusiasme siswa dalam mengikuti pembelajaran.

\section{DAFTAR RUJUKAN}

Agustinawati, N. (2014). Pengaruh Metode Pembelajaran dan Kemandirian Belajar Terhadap Hasil Belajar Sejarah Siswa di SMAN 7 Cirebon. Jurnal Pendidikan Sejarah, 3(2), 1-7. 
Arikunto, S. (2006). Prosedur suatu pendekatan praktek. Jakarta: Rineka Cipta.

Budiawan, M. (2013). Pengaruh model pembelajaran kooperatif tipe jigsaw dan motivasi belajar terhadap prestasi belajar ilmu fisiologi olahraga. JPI (Jurnal Pendidikan Indonesia), 2(1).

Chrisnawati, H. E. (2007). Pengaruh penggunaan metode pembelajaran kooperatif tipe STAD (student teams achievement divisions) terhadap kemampuan problem solving siswa smk (teknik) swasta di Surakarta ditinjau dari motivasi belajar siswa.

Delviani, D., Djuanda, D., \& Hanifah, N. (2016). Penerapan Model Kooperatif Tipe Circ (Cooperative Integrated Reading And Composition) Berbantuan Media Puzzle Kalimat Untuk Meningkatkan Kemampuan Membaca Anak Dalam Menentukan Pikiran Pokok. Jurnal Pena Ilmiah, 1(1), 91-100.

Dörnyei, Z. (1997). Psychological processes in cooperative language learning: Group dynamics and motivation. The Modern Language Journal, 81(4), 482-493.
Elliot, J. (1991). Action research for educational change. McGraw-Hill Education (UK).

Eviliyanto, \& Gultom, T. M. (2017). Model Pembelajaran Cooperative Integrated Reading And Composition (CIRC) Untuk Peningkatan Aktivitas Belajar Siswa Pada Mata Pelajaran Geografi. Paedagogia, 20(1), 1123.

Farboy, S. (2013). Penerapan metode cooperative integrated reading and composition (circ) untuk meningkatkan kemampuan menemukan gagasan utama sebuah teks pada siswa kelas VII di SMP Negeri 3 Batu tahun ajaran 2008/2009. Jurnal Artikulasi, 7(1).

Halimah, A. (2014). Metode cooperative integrated reading and composition (circ) dalam pembelajaran membaca dan menulis di $\mathrm{sd} / \mathrm{mi}$. AULADUNA: Jurnal Pendidikan Dasar Islam, 1(1), 27-35.

Hasan, H. (2015). Kendala yang Dihadapi Guru dalam Proses Belajar Mengajar Matematika di SD Negeri Gani Kabupaten Aceh Besar. Jurnal Pesona Dasar, 1(4).

Husna, H., \& Pinem, K. (2011). Perbedaan Hasil Belajar Siswa Antara Pengajaran Multimedia dengan Pengajaran Konvensional 
Pada Materi Iklim Global di Kelas X SMA N 1 Seruway Kabupaten Aceh Tamiang TP 2009/2010. JURNAL GEOGRAFI, 3(2), 83-93.

Kariesma, I. K. W., Zulaikha, S., Ganing, N. N., \& Hum, M. (2014). Pengaruh Model Pembelajaran CIRC Bermedia Powerpoint terhadap Keterampilan Membaca Pada Bahasa Indonesia Kelas IV SD Gugus I Kuta Badung. MIMBAR PGSD Undiksha, 2(1).

Kurniaman, O., \& Noviana, E. (2016).

Metode Membaca Sas (Struktural Analitik Sintetik) dalam Meningkatkan Keterampilan Membaca Permulaandi Kelas I Sdn 79 Pekanbaru. Primary, 5(2), 149157.

Kusumah, W., \& Dwitagama, D. (2010). Mengenal penelitian tindakan kelas edisi kedua. Yogyakarta: PT. Indeks.

Maisaroh, S. (2011). Upaya Peningkatkan Motivasi Dan Prestasi Belajar Ips Melalui Model Pembelajaran Kooperatif Tipe Teams Games Tournament. Dinamika Pendidikan, 6(2), 150 169.

Mulyana, M. A., Hanifah, N., \& Jayadinata, A. K. (2016). Penerapan model kooperatif tipe numbered heads together (NHT) untuk meningkatkan hasil belajar siswa pada materi kenampakan alam dan sosial budaya. Jurnal Pena Ilmiah, 1(1), 331-340.

Nichols, J. D., \& Miller, R. B. (1994).

Cooperative learning and student motivation. Contemporary Educational Psychology, 19(2), 167-178.

Nuraisah, E., Irawati, R., \& Hanifah, N. (2016). Perbedaan Pengaruh Penggunaan Pembelajaran Konvensional dan Pendekatan Kontekstual Terhadap Kemampuan Berpikir Kritis Matematis dan Motivasi Belajar Siswa Pada Materi Pecahan. Jurnal Pena Ilmiah, 1(1), 291-300.

Pratita, I. I. (2017). Pengembangan Model Cooperative Integrated Reading And Composition (CIRC) untuk Meningkatkan Kemampuan Membaca Pemahaman (Dokkai) Mahasiswa Jurusan Bahasa dan Sastra Jepang Universitas Negeri Surabaya. $A S A, 4(1)$.

Pratiwi, C. W. (2012). Meningkatkan Kemampuan Memahami Cerita Pada Pembelajaran Bahasa Indonesia Melalui Penerapan Metode CIRC (Cooperative Integrated Reading and Composition) Siswa Kelas IV SD Muhammadiyah 7 Surakarta Tahun 
Pelajaran 20011/2012. Universitas

Muhammadiyah Surakarta.

Purba, N. A. (2018). Kemampuan Menemukan Ide Pokok Paragraf Berbagai Jenis Wacana Dalam Naskah Soal Uas Oleh Siswa Kelas IX SMP Negeri 5 Percut Sei Tuan. Bina Gogik: Jurnal Ilmiah Pendidikan Guru Sekolah Dasar, 5(1).

Purnawasari, W. I. (2017). Pengaruh Model Pembelajaran Kooperatif Tipe Circ (Cooperative Integrated Reading And Composition) Terhadap Kemampuan Menemukan Kalimat Utama Dalam Paragraf Pada Siswa Kelas Iv Sdn Blimbing Dan Kalirong 2 Tahun Ajaran 2016/2017. Jurnal SimkiPedagogia, 1(02).

Putrawan, I. G. A. R., Sudana, D. N., \& Tastra, I. D. K. (2017). Pengaruh Model Pembelajaran CIRC (Cooperative Integrated Reading And Composition) terhadap Literasi Siswa Kelas III SD. MIMBAR PGSD Undiksha, 5(2).

Rahmawati, R. (2017). Strategi Pembelajaran Membaca dan Menulis Permulaan Melalui Media Kata Bergambar. SAP (Susunan Artikel Pendidikan), 1(3).

Ramadhanti, D. (2017). Penerapan Model Pembelajaran Kooperatif
Tipe CIRC dalam Pembelajaran Menulis Narasi Siswa Kelas VII SMP Negeri 2 Lembah Gumanti. Jurnal Gramatika: Jurnal Penelitian Pendidikan Bahasa dan Sastra Indonesia, 3(1), 27-42.

Rapita, R. (2018). Kemampuan Menentukan Ide Pokok Paragraf Melalui Model Pembelajaran One To One Siswa Kelas VII SMP Negeri 3 Bastem. Jurnal Onoma: Pendidikan, Bahasa, dan Sastra, $3(2)$.

Samniah, N. (2015). Kemampuan memahami isi bacaan siswa kelas VII Mts Swasta Labibia. Jurnal Humanika, 3(16).

Saparwadi, L. (2016). Efektivitas Metode Pembelajaran Drill dengan Pendekatan Peer Teaching Ditinjau dari Minat dan Prestasi Belajar Matematika Siswa. Jurnal Didaktik Matematika, 3(1), 39-46.

Sastika, A. R., \& Vh, E. S. (2013). Implementasi metode pembelajaran circ (cooperative integrated reading and composition) yang dilengkapi media macromedia flash pada materi pokok sistem koloid kelas xi ipa semester genap sma negeri 3 sragen tahun ajaran 2011/2012. Jurnal Pendidikan Kimia, 2(3), 4248.

Sofiyah, S. (2015). Meningkatkan Kemampuan Membaca Permulaan 
dengan Menggunakan Media Gambar pada Siswa Kelas II SDN 2 Wosu Kecamatan Bungku Barat Kabupaten Morowali. Jurnal Kreatif Online, 3(2).

Sudjana, N. (2009). Penilaian Hasil Belajar Proses Belajar Mengajar. Bandung: PT Remaja Rosdakarya.

Sukaryantini, M. (2013). Upaya Meningkatkan Kemampuan Memahami Nilai-Nilai Edukatif Dalam Cerpen Melalui Model Circ (Cooperative Integrated Reading And Composition) Siswa Kelas Xi Ips1 Di Sma Saraswati Seririt. Jurnal Pendidikan Bahasa dan Sastra Indonesia Undiksha, 1(6).

Supangat, S. (2016). Penerapan Model Pembelajaran Circ (Cooperative Integrated Reading And Composition) Untuk Meningkatkan Kemampuan Membaca Dan Menulis Siswa Pada Mata Pelajaran Kitab Kuning Di Pondok Pesantren. Al-I'tibar: Jurnal Pendidikan Islam, 2(1), 124-142.

Taqwa, M. R. A. (2018). Kekeliruan Memahami Konsep Gaya, Apakah Pasti Miskonsepsi? Jurnal Inovasi Pendidikan Fisika Dan Integrasinya, 1(02), 1-12.

Taqwa, M. R. A., Astalini, \& Darmaji. (2015). Hubungan Gaya Belajar Visual, Auditorial, dan Kinestetik dengan Hasil Belajar Siswa Pada Materi Dinamika Rotasi dan Kesetimbangan Benda Tegar Kelas XI IPA SMA Se-Kota Jambi. 220227. Purworejo: Universitas Purworejo.

Taqwa, M. R. A., \& Faizah, R. (2016). Perlunya program resitasi untuk meningkatkan kemampuan mahasiswa dalam memahami konsep gaya dan gerak. Pros. Semnas Pend. IPA Pascasarjana UM, 365-372. Malang: Universitas Negeri Malang.

Taqwa, M. R. A., Faizah, R., \& Rivaldo, L. (2019). Pengembangan Lembar Kerja Mahasiswa Berbasis POE Dan Kemampuan Berpikir Kritis Mahasiswa pada Topik Fluida Statis. Edufisika: Jurnal Pendidikan Fisika, 4(01), 6-13.

Taqwa, M. R. A., \& Hidayat, A. (2017). Deskripsi Penggunaan Program Resitasi dalam Meningkatkan Kemampuan Membangun FreeBody Diagrams (FBDs). Jurnal Pendidikan Fisika Tadulako, 5(1), 52-58.

Triandy, R. (2017). Pembelajaran Mengidentifikasi Ide Pokok Dalam Artikel Dengan Metode Inquiry Pada Siswa Kelas X Sma Pasundan 2 Bandung. LITERASI: Jurnal Ilmiah Pendidikan Bahasa, Sastra 
Indonesia dan Daerah, 7(2), 143152.

Tristiantari, N. K. D., \& Sumantri, I. M. (2016). Model Pembelajaran Cooperatif Integrated Reading Composition Berpola Lesson Study Meningkatkan Keterampilan Membaca Dan Menulis. JPI (Jurnal Pendidikan Indonesia), 5(2), 203-211.

Yeni, L. F., \& Kalsum, U. (2012). Efektivitas Model Pembelajaran Cooperative Integrated Reading And Composition (CIRC) Terhadap Hasil Belajar Siswa Pada Sub Materi Pencemaran Lingkungan Di Kelas X Sma Negeri 4 Pontianak. Jurnal Visi Ilmu Pendidikan, 8(2).

Yudasmini, N. M., Marhaeni, A. A. I. N., \& Jampel, N. (2015). Pengaruh Model Pembelajaran Circ terhadap Minat Baca dan Kemampuan Memahami Bacaan pada Siswa Kelas VI di Sekolah Dasar Gugus Buruan. Jurnal Penelitian dan Evaluasi pendidikan Indonesia, $5(1)$.

Yuliana, D., Walanda, D. K., \& Ratman, R. (2014). Penerapan Model Pembelajaran Koopeartif Tipe Cooperative, Integrated, Reading and Composition (CIRC) Pada Materi Struktur Atom dan Sistem Periodik Unsur Kelas X SMAN 1
Pasangkayu. Jurnal Akademika Kimia, 3(1), 50-56.

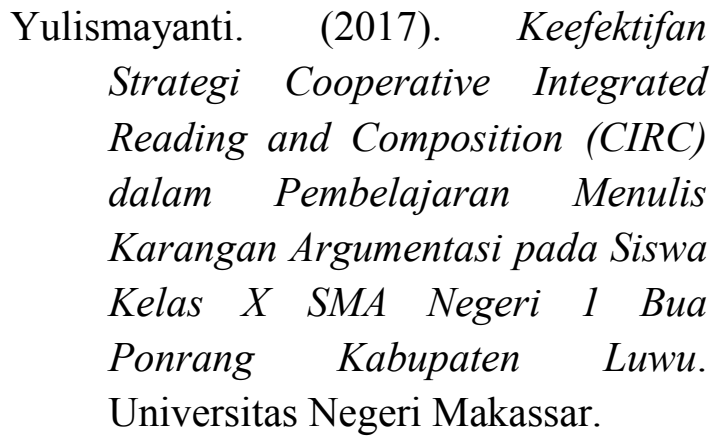

